\title{
Terminological subset of the International Classification for Nursing Practice for patients hospitalized due to burns
}

\author{
Subconjunto Terminológico da Classificação Internacional para a Prática de \\ Enfermagem para pacientes hospitalizados por queimaduras \\ Subconjunto Terminológico de Clasificación Internacional de la Práctica de \\ Enfermería para pacientes hospitalizados por quemaduras
}

How to cite this article:

Silva ITS, Menezes HF, Souza Neto VL, Sales JRP, Sousa PAF, Silva RAR. Terminological subset of the International Classification for Nursing Practice for patients hospitalized due to burns. Rev Esc Enferm USP. 2021;55:e20200502. doi: https://doi.org/10.1590/1980-220X-REEUSP-2020-0502

Ilisdayne Thallita Soares da Silva ${ }^{1}$

Harlon França de Menezes ${ }^{2}$

Vinicius Lino de Souza Neto ${ }^{3}$

José Renato Paulino de Sales ${ }^{1}$

Paulino Artur Ferreira Sousa ${ }^{4}$

Richardson Augusto Rosendo da Silva ${ }^{5}$

${ }^{1}$ Universidade Federal do Rio Grande do Norte, Natal, RN, Brazil.

${ }^{2}$ Universidade Federal Fluminense, Escola de Enfermagem Aurora de Afonso Costa, Programa Acadêmico em Ciências do

Cuidado em Saúde, Niterói, RJ, Brazil.

${ }^{3}$ Universidade Federal de São Paulo, São Paulo, SP, Brazil.

${ }^{4}$ Escola Superior de Enfermagem do Porto, Porto, PT, Portugal.

${ }^{5}$ Universidade Federal do Rio Grande do Norte, Departamento de Enfermagem, Programa de Pós-Graduação em Enfermagem, Natal, RN, Brazil.

\section{ABSTRACT}

Objective: To develop a proposal of a terminological subset of the International Classification for Nursing Practice for burned patients. Method: This is a methodological study following the steps: identification of clinical findings; mapping of terms; construction of statements of diagnoses/results and nursing interventions; content validation of statements; and structuring of the subset with the theoretical model of Basic Human Needs. Content validation was performed by 26 specialist nurses, through the Content Validity Index, with statements $\geq 0.80$ being considered validated. Results: A total of 36 diagnoses/results and 119 interventions were validated. Among these, the ones with the highest index were: Respiratory System Function, Impaired/Respiratory System Function, Effective; Volume of Fluids, Impaired/ Volume of Fluids, Effective; Burn Wound/Wound Healing, Effective; Pain, Acute/ Pain, Absent, and as interventions: To Monitor Vital Signs; to Monitor Fluid Balance; to Treat Skin Condition; to Assess Response to Pain Management (Control). Conclusion: The validated statements depict the burned people basic human needs, with the psychobiological ones being the most prevalent.

\section{DESCRIPTORS}

Burns; Nursing Care; Nursing Process; Standardized Nursing Terminology; Classification. 


\section{INTRODUCTION}

Burns are characterized as rupture and loss of outer or deeper layers of tissue on the body surface, due to heat injuries, from exposure to thermal, chemical, electrical, or radioactive agents, and are responsible for a high mortality rate in Brazil, since approximately one million people are involved in burns per year, of which 40 thousand require hospitalization $^{(1-2)}$.

This condition is decisive in the population's morbidity profile, because, depending on factors such as its extent and severity, they can leave consequences with physical and emotional impacts that are difficult to be measured ${ }^{(2)}$. To provide assistance to burned people, nurses have to use an approach that meets human needs, with strategies planning and a set of interventions to allow achieving the objectives proposed through their work method ${ }^{(3)}$.

The way nurses work can be facilitated by the implementation of nursing classification systems, among them the International Classification for Nursing Practice (ICNP $\left.{ }^{\circledR}\right)$. This is a standardized, broad, and complex language system, which represents the mastering of nursing practice worldwide, being considered a unifying landmark of the different classification systems of the elements of professional practice, as it groups statements of diagnoses, results, and nursing interventions, that is, elements of a terminological subset ${ }^{(4-5)}$.

The production focused on the theme becomes relevant since there are few studies involving the development of nursing diagnoses, results, and interventions for people with burns and the use of classification systems ${ }^{(6-7)}$. In addition, a study points to the use of $\mathrm{ICNP}^{\circledR}$ in several areas, such as: colostomized patient, domestic violence against children and adolescents, care for women and children in the breastfeeding process, prostatectomized patient, community-based elderly, palliative care, and people hospitalized with the acquired immunodeficiency syndrome; thus, it can be observed that there is a gap in what regards the studies with the burned person, a fact that justifies the research ${ }^{(8)}$.

Therefore, the elaboration of a terminological subset may contribute to the care process based on systematic practices, allowing nurses to look carefully at the priority needs in the care of burned patients, demonstrating the relevance of the study. In this regard, the following question arose: can the diagnoses, results, and nursing interventions identified in hospitalized patients with burns using the $\mathrm{ICNP}^{\circledR}$ and classified according to the human needs by Horta be structured in a terminological subset for burned patients? In view of the above, the objective is to develop a proposal for a terminological subset of the $\mathrm{ICNP}^{\circledR}$ for burned patients.

\section{METHOD}

\section{Design of Study}

This is a methodological study in a Burn Treatment Center (CTQ), in a state hospital in the city of Natal, $\mathrm{RN}$, in the Northeast region of Brazil, and divided into five steps, which followed the guidelines of the Brazilian method for the development of terminological subsets ${ }^{(4)}$ : 1) Identification of the indicators of affected basic human needs through interviews and physical examination; 2) Mapping of the terms identified in the interview and physical examination with the terms of the $\mathrm{CIPE}^{\circledR}$, version 2019/2020 (1); 3) Construction of the statements of diagnoses, results, and nursing interventions; 4) Content validation of nursing diagnoses, results, and interventions; and 5) Structuring of the terminology subset $\operatorname{ICNP}^{\circledR}$ for the burned person with the theoretical model of Basic Human Needs ${ }^{(9)}$.

\section{Population}

The population consisted of hospitalized patients and specialist nurses. First, the patients sample calculation was based on the annual arithmetic average of people assisted between 2013 and 2017, totaling 300.2. Thus, the formula for finite populations was used, considering the $95 \%$ confidence level $\left(Z_{\infty}=1.96\right)$, the sample error of $5 \%$, and the population size.

The selection of 120 patients was a convenience, consecutive sampling, with the following eligible inclusion criteria being adopted: age over 18 years, being admitted to the burn center during the data collection period. The following exclusion criteria were adopted: those patients who had some type of mental disorder, assessed through the Mini Mental State Examination ${ }^{(10)}$.

To search for specialist nurses, the Lattes Platform, of the National Council for Scientific and Technological Development $(\mathrm{CNPq})$, was used, with the term "burn" as a subject of search. In addition, the homepage criteria were adopted: Educational background/Titles: All; Country: Brazil; Region/State: All; and Professional Practice: Major Area: Health Sciences; Area: Nursing; Subarea: Adult and Elderly Health Nursing; Specialty: All. This search allowed reaching 210 nurses. The sample adopted in the research was based on the precepts that deduce that the minimum number of specialists shall be 25 and the ideal number 50 , according to Fehring's model ${ }^{(11)}$. Thus, the specialists were intentionally selected and the following eligibility criteria were adopted: 1) Master's Degree in Nursing: 2 points; 2) Master's Degree in Nursing with thesis focused on the thematic area of the study: 1 point; 3 ) Publication of an article on nursing diagnoses with content relevant to the area in focus: 2 points; 4) $\mathrm{PhD}$ degree in the thematic area: 4 points; 5) Clinical experience of at least one year in the study area: 1 point; 6) Certificate of clinical practice relevant to the area under study: 2 points. In this respect, 50 specialists who obtained the highest scores were selected, but 26 returned the script.

The patients were from 19 years to 31 years old $(57.15 \%)$. Most were men (52.35\%), married (60.15\%), self-employed (49.08\%), white (64.11\%), and Catholics (75.36\%). Regarding the characterization of specialist nurses, the majority were women $(68.47 \%)$, with a minimum age of 21 years and a maximum of 62 years, mean age of 39.13 years, working in the area for 5 to 10 years. 


\section{Data Collection}

In the first step, carried out between August and October 2018, indicators of affected basic human needs were identified, with clinical terms and findings ${ }^{(12)}$, and an interview and physical examination script was provided, being structured on the basic human needs by Horta. This instrument was adapted to the reality by the researchers in this study and hospital nurses. It contemplates: sociodemographic and clinical data, and clinical findings of basic human psychobiological, psychosocial, and psycho-spiritual needs. The terms were classified in the 7-Axis Model (Focus, Judgment, Means, Action, Time, Location and Client).

In the second step, the related terms were manually selected and entered into a spreadsheet in the Microsoft Office Excel $^{\circledR}$ software. Cross-mapping was performed using two tables: one with the first step terms and the other with the terms of the ICNP ${ }^{\circledR}$ axes, with synonyms and repetitions being eliminated, as dictated by the International Organization For Standardization (ISO) 12.300:2016 standard ${ }^{(13)}$. This step was elaborated after the first one, being compared to the version of $\mathrm{ICNP}^{\circledR}$ 2017 in force at the time; however, to update the data, the mapping was carried out with the 2019/2020 version. This way, the mapping proves to be a process of continuous improvement, allowing terminology updating ${ }^{(13)}$.

In the third step, the diagnosis/results statements were elaborated after the previous steps, and consisted of a term from the Focus Axis and another from Judgment Axis, or a clinical finding, following the recommendations of the International Council of Nurses (ICN) and the ISO 18.104:2014 standards; for the elaboration of the statements of nursing interventions, a term from the Action Axis and target terms were used. To elaborate the operational definitions of the constructed statements, three steps were taken: literature review; mapping of the concept meaning; and affirmation of the operational definition ${ }^{(14)}$. The diagnoses, results, and nursing interventions were prepared only with statements contained in the $\mathrm{ICNP}^{\circledR}$, accompanied by their respective codes.

Then, a database was built using the Microsoft Office Excel ${ }^{\circledR}$ software with the respective diagnoses, results, and nursing interventions for burned people. Thus, the experts' assignment was to assess whether the proposed statements were applicable to the clientele. In case of disagreement, it was requested that suggestions be made for its adequacy to the reality of nursing practice.

Participation invitations were made via e-mail, and those invited were sent the Free and Informed Consent Form. Following this step, the link to the electronic form to be filled out was sent, which had the following information: nurses' characterization, and a list of the diagnoses, results, and nursing interventions statements. It was proposed that the return should occur within 30 days. The validation process took place in November 2019.

\section{Data Analysis and Treatment}

Data were analyzed using descriptive statistics. To analyze the degree of agreement among the specialists, the Content Validation Index (CVI) was chosen, a five point Likert scale was developed: 1 = not pertinent; 2 = slightly pertinent; $3=$ very pertinent; $4=$ pertinent; $5=$ extremely pertinent, for measuring the relevance of the statements for the nursing practice applied to burned patients. Then, a weighted arithmetic average of the grades given by each specialist was calculated to obtain the CVI. In this regard, the diagnoses that obtained the $\mathrm{CVI}>0.80$ were considered validated.

\section{Ethical AspeCts}

The research was approved by the Research Ethics Committee of the Universidade Federal do Rio Grande do Norte in accordance with opinion no. 1.450.346, approved on March 14, 2016, since all the ethical precepts of Resolution no. 466 of 2012, from the National Health Council, were followed.

\section{RESULTS}

A total of 942 terms were extracted from the interviews and physical examinations, and were subjected to the process of exclusion of repetitions, normalization, and standardization according to $\mathrm{ICNP}^{\circledR} 2019$ and, at the end, there were 327 terms. Terms mapping identified 278 constant and 49 non-constant terms in $\mathrm{ICNP}^{\circledR}$. The constant terms arrangement according to the ICNP ${ }^{\circledR} 7$-Axis Model resulted in: 219 terms on the focus axis; 21 on the Judgment Axis; 36 on the Means Axis; 29 on the Action Axis; 06 on the Time Axis; 13 on the Location Axis; and three on the Client Axis.

Thus, it was possible to elaborate 40 nursing diagnoses/ results. After the content validation process, the recommendations and suggestions received from the specialists resulted in 36 validated nursing diagnoses/results. Of these, 26 were classified within the psychobiological needs, nine in the psychosocial, and only one in the psycho-spiritual need (Chart 1).

For the statements of diagnoses/results elaborated, 132 nursing interventions were agreed, with the general lines of the Brazilian method, the clinical reasoning, and the experience of the authors being considered. Of the 132 nursing interventions constructed, 119 achieved CVI $\geq 0.80$ (Chart 2).

\section{DISCUSSION}

In clinical nursing care for burned patients, care shall not be focused only on the biological dimension, but include a holistic approach considering the individual as a being who also has spiritual, social, and psychological needs, especially because it is a human being exposed to a condition considered devastating ${ }^{(15)}$. In this regard, the relevance of the Theory of Basic Human Needs stands out in nursing care for burned victims and in the organization of the terminological subset in a global manner. 
Chart 1 - Distribution of ICNP ${ }^{\oplus}$ diagnoses and results statements organized according to Human Basic Needs - Natal, RN, Brazil, 2020.

\begin{tabular}{|c|c|}
\hline Human Needs & Nursing Diagnoses and Results \\
\hline & Human Psychobiological Needs \\
\hline Oxygenation & Respiratory System Function, Impaired (10023362)/Respiratory System Function, Effective (10028160) \\
\hline \multirow{3}{*}{ Hydration } & Fluid Volume, Impaired (10042008)/Fluid Volume, Effective (10042054) \\
\hline & Fluid Imbalance (10042335)/Fluid Imbalance (or Water Balance), within Normal Limits (10033721) \\
\hline & Dehydration (10041882)/Hydration, Adequate (10042065) \\
\hline Nutrition & Nutritional Status, Impaired (10025746)/Nutritional Status, Positive (10025002) \\
\hline Elimination & Urinary Status, Impaired (10026766)/Urinary Status, Effective (10026766) \\
\hline \multirow{2}{*}{ Sleep and Rest } & Resting Behavior, Impaired (10017129)/Resting Behavior, Positive (10017129) \\
\hline & Fatigue (10000695)/Fatigue, Absent (10034727) \\
\hline \multirow{3}{*}{ Exercise and Physical Activities } & Ability to Walk, Impaired (10000258)/Ability to Walk, Effective (10000258) \\
\hline & Active Range of Motion, Impaired (10052095)/Range of Motion, Active (10052076) \\
\hline & Musculoskeletal System Function, Impaired (10022642)/Musculoskeletal System Function, Effective (10028092) \\
\hline Body Care & Ability to Perform Self-Care, Impaired (10023729)/Ability to Perform Self-Care, Positive (10025311) \\
\hline \multirow{2}{*}{ Cutaneous-mucous Integrity } & Skin Integrity, Impaired (10001290)/Skin Integrity, Improved (10028517) \\
\hline & Burn Wound (10029737)/Wound Healing, Effective (10035096) \\
\hline \multirow{3}{*}{ Physical Integrity } & Aspiration Risk (10015024)/Absent Aspiration Risk (10015024) \\
\hline & Risk of Infection/Absent Risk of Infection \\
\hline & Infection (10015133)/Infection, Absent (10028945) \\
\hline Thermal Regulation & Thermoregulation, Impaired (10033560)/Thermoregulation, Effective (10033848) \\
\hline Neurological Regulation & Agitation (10002035)/Agitation, Reduced (10027843) \\
\hline \multirow{5}{*}{ Vascular Regulation } & Hypovolemic Shock (10009599)/Hypovolemic Shock, Absent (10009599) \\
\hline & Septic Shock (10017898)/Septic Shock, Absent (10017898) \\
\hline & Edema (10041951)/Edema, Absent (10029020) \\
\hline & Heart Rate, Altered (10008833)/Heart Rate, within Normal Limits (10029229) \\
\hline & Risk of bleeding (10017268)/Absent risk of bleeding (10017268) \\
\hline Pain Perception & Pain, Acute (10023130)/Pain, Absent (10023130) \\
\hline Therapy & Attitude towards Care, Conflicting (10022281)/Attitude towards Care, Positive (10022275) \\
\hline \multicolumn{2}{|r|}{ Human Psychosocial Needs } \\
\hline \multirow{4}{*}{ Safety } & Anxiety (10000477)/Anxiety, Reduced (10027858) \\
\hline & Fear (10000703)/Fear, Reduced (10027889) \\
\hline & Sadness (10040662)/Sadness, Reduced (10027862) \\
\hline & Response to Trauma, Impaired (10020114)/Response to Trauma, Improved (10027760) \\
\hline Love & Family Support, Impaired (10023680)/Family Support, Positive (10045702) \\
\hline Communication & Communication, Impaired (10023370)/Communication, Effective (10014828) \\
\hline Gregariousness & Social Isolation (10001647)/Social Isolation, Decreased (10050070) \\
\hline Space & Lack of Privacy (10025601)/Privacy, Improved (10025590) \\
\hline Self-image & Body Image, Disturbed (10001079)/Body Image, Positive (10028564) \\
\hline \multicolumn{2}{|r|}{ Human Psycho-spiritual Needs } \\
\hline Spirituality & Spiritual Anguish (10001652)/Spiritual Anguish, Decreased (10027149) \\
\hline
\end{tabular}


Chart 2 - Distribution of ICNP ${ }^{\oplus}$ nursing interventions concepts organized according to Human Basic Needs - Natal, RN, Brazil, 2020.

\begin{tabular}{|c|c|}
\hline \multicolumn{2}{|r|}{ Nursing Interventions } \\
\hline \multicolumn{2}{|r|}{ Human Psychobiological Needs } \\
\hline Oxygenation & $\begin{array}{l}\text { Raise Head and Thorax (10017782); Monitor Blood Oxygen Saturation Using Pulse Oximeter (10032047); Listen to the } \\
\text { Lung (10050592); Measure (or Check) Respiratory Movements (10046338); Monitor acid-base balance (10051643); Monitor } \\
\text { Respiratory Therapy (10037092); Obtain Respiratory Status Data Using a Monitoring Device (10002799) }\end{array}$ \\
\hline Hydration & $\begin{array}{l}\text { Monitor Vital Signs (10032113); Measure (or Check) Fluid Output (10039250); Promote Urinary Elimination, Effective (10036729); } \\
\text { Monitor Fluid Balance (or Water Balance) (10040852); Obtain Data on Urinary Status (10036499); Manage Hemodynamic Status } \\
\text { (10051572); Manage Hydration (10046317); Manage Fluid Therapy (or Hydration) (10042096); Instruct on Fluid Therapy (or } \\
\text { Hydration) (10043813); Assess Response to Fluid Therapy (or Hydration) (10007176) }\end{array}$ \\
\hline Nutrition & $\begin{array}{l}\text { Monitor Nutrition (10036032); Obtain Data on Food Intake (10050091); Assist in Food or Liquid Intake (10037269); Promote } \\
\text { Nutritional Status, Positive (10050920); Monitor Weight (10032121) }\end{array}$ \\
\hline Elimination & $\begin{array}{l}\text { Assess Genitourinary Status (10034011); Obtain Data on Urinary Status (10036499); Urinary Catheter Care (10033277); Obtain } \\
\text { Data on Urinary Status (10036499); Promote Urinary Elimination, Effective (10036729) }\end{array}$ \\
\hline $\begin{array}{l}\text { Exercise and } \\
\text { Physical } \\
\text { Activities }\end{array}$ & $\begin{array}{l}\text { Obtain Data on Ability to Walk (10038917); Instruct on Ambulation Technique (10037461); Prepare the Patient for Exercise } \\
\text { (10051783); Promote Adherence to the Physical Exercise Regime (10041628); Obtain Data on Fine Motor Function (10050210); } \\
\text { Obtain Data on Body Movement (10050223); Perform Range of Motion, Passive (10043527); Emphasize Muscle or Joint Exercise } \\
\text { Technique (10036512); Obtain Data on Fine Motor Function (10050210); Promote Use of Progressive Muscle Relaxation } \\
\text { Technique (10040564); Obtain Data on Range of Motion, Active (10040044); Evaluate Musculoskeletal Status (10034030) }\end{array}$ \\
\hline $\begin{array}{l}\text { Physical } \\
\text { Integrity }\end{array}$ & $\begin{array}{l}\text { Position Patient (10014761); Monitor Blood Oxygen Saturation Using Pulse Oximeter (10032047); Listen to the Lungs } \\
\text { (10050592); Prevent Aspiration (10051810); Maintain Permeable Airways (10037351); Monitor Laboratory Results (10032099); } \\
\text { Obtain Hyperthermia Risk Data (10033905); Assess Risk of Infection after Surgery (10034048); Assess Symptoms and Signs of } \\
\text { Infection after Surgery (10034069); Obtain Data on Infection Symptoms and Signs (10044182); Obtain Infection Susceptibility } \\
\text { Data (10002821); Advise on Cross Infection Prevention (10038112); Monitor Infection Symptoms and Signs (10012203); Evaluate } \\
\text { Wound Healing (10007218) }\end{array}$ \\
\hline Body Care & $\begin{array}{l}\text { Obtain Data on Self-Care (10021844); Instruct on Self-Care (10045014); Promote Self-Care (10026347); Obtain Data on Skin } \\
\text { Self-Care (10030747); Instruct on Skin Self-Care (10033029) }\end{array}$ \\
\hline $\begin{array}{l}\text { Vascular } \\
\text { Regulation }\end{array}$ & $\begin{array}{l}\text { Assess Response to Fluid Therapy (or Hydration) (10007176); Monitor Fluid Output (10035319); Measure (or Check) Fluid } \\
\text { Output (10039250); Monitor Fluid Balance (or Water Balance) (10040852); Prevent Shock (10051847); Measure (or Check) } \\
\text { Heart Rate (10036826); Report Condition to the Interprofessional Team (10042645); Monitor Infection Symptoms and Signs } \\
\text { (10012203); Obtain Data on Infection Symptoms and Signs (10044182); Obtain Data on Edema (10045177); Maintain Skin } \\
\text { Integrity (10035293); Monitor Liquid Balance (or Water Balance) (10040852); Obtain Data on Peripheral Tissue Perfusion } \\
\text { (10042856); Monitor Blood Pressure (10032052); Monitor Heart Condition (10034285); Obtain Data on Heart Status Using a } \\
\text { Monitoring Device (10002706); Manage Bleeding (10050690); Monitor Laboratory Results (10032099); Obtain Data on Tissue } \\
\text { Perfusion (10030775); Care with Invasive Device Location (10031592); Identify Hemorrhage Risk (10009696) }\end{array}$ \\
\hline $\begin{array}{l}\text { Thermal } \\
\text { Regulation }\end{array}$ & $\begin{array}{l}\text { Obtain Data on Thermoregulation Risk, Negative (10033914); Promote Thermoregulation, Positive (10015817); Evaluate } \\
\text { Response to Thermoregulation (10007195) }\end{array}$ \\
\hline $\begin{array}{l}\text { Neurological } \\
\text { Regulation }\end{array}$ & $\begin{array}{l}\text { Obtain Data on the Environment (10026064); Reality Orientation Therapy (10041072); Decrease Noise (10050384); Agree on } \\
\text { Positive Behavior (10035771) }\end{array}$ \\
\hline Pain Perception & $\begin{array}{l}\text { Instruct on Pain Management (Control) (10019489); Analgesia Controlled by Nurse (o) (10039798); Assess Response to Pain } \\
\text { Management (Control) (10034053); Assess Psychosocial Response to Instruction on Pain (10007148) }\end{array}$ \\
\hline Therapy & $\begin{array}{l}\text { Instruct the patient (10033126); Instruct the Patient on Therapeutic Regimen (10024625); Obtain Knowledge Data on Therapeutic } \\
\text { Regimen (10036481); Obtain Data on Attitude towards the Therapeutic Regimen (10024205); Reinforce Communication } \\
\text { (10050309) }\end{array}$ \\
\hline \multicolumn{2}{|r|}{ Human Psychosocial Needs } \\
\hline Communication & $\begin{array}{l}\text { Identify Communication Barriers (10009683); Facilitate Capacity to Communicate Needs (10038196); Establish Trust (10024396); } \\
\text { Facilitate Access to Treatment (10024401); Advise on Communication, Effective (10036169) }\end{array}$ \\
\hline Gregariousness & $\begin{array}{l}\text { Facilitate Ability to Communicate Feelings (10026616); Advise on Hope (10026212); Support Beliefs (10026458); Assess } \\
\text { Psychosocial Response to the Care Plan (10007153); Engage in the Decision-Making Process (10026323) }\end{array}$ \\
\hline Safety & $\begin{array}{l}\text { Obtain Data on Anxiety (10041745); Manage Anxiety (10031711); Support Psychological Condition (10019161); Manage } \\
\text { Anxiety (10031711); Support Capacity to Manage the Regimen (10032800); Advise on Fears (10026208); Obtain Data on } \\
\text { Fear (10024267); Obtain Data on Fear of Putting a Burden on Others (10026254); Obtain Data on Fear of Death (10026093); } \\
\text { Obtain Data on Sadness (10038940); Obtain Data on Mood, Depressed (10026055); Provide (Promote, Give) Emotional Support } \\
\text { (10027051); Assess Adherence to the Therapeutic Regimen (10044153); Facilitate Adherence to the Regimen (10036273); Get } \\
\text { Data on Negation (10024246); Promote Hope (10024440) }\end{array}$ \\
\hline
\end{tabular}

continue... 


\begin{tabular}{|c|c|}
\hline \multicolumn{2}{|r|}{ Nursing Interventions } \\
\hline Love & $\begin{array}{l}\text { Support Family Coping Process (10032859); Promote Family Support (10036078); Provide (Promote, Give) Emotional Support } \\
\text { (10027051); Emphasize Personal Identity (10026443); Monitor Family Coping, Impaired (10032068) }\end{array}$ \\
\hline Self-image & Obtain Data on Body Image (10045891); Support Body Image, Positive (10044531) \\
\hline Space & Maintain Dignity and Privacy (10011527); Provide (Promote, Give) Privacy (10026399) \\
\hline \multicolumn{2}{|r|}{ Human Psycho-spiritual Needs } \\
\hline Spirituality & $\begin{array}{l}\text { Obtain Data on Spiritual Condition (10030768); Obtain Data on Spiritual Beliefs (10024308); Promote Spiritual Support } \\
\text { (10038300); Provide (Promote, Give) Privacy for Spiritual Behavior (10024504); Advise on Spiritual Anguish (10026231); } \\
\text { Promote Hope; Promote Coping, Effective (10035936) }\end{array}$ \\
\hline
\end{tabular}

Concerning the psychobiological needs, most of their diagnoses were related to oxygenation and vascular regulation; hydration and electrolytic regulation; thermal regulation, body care and cutaneous-mucosal integrity; immunological regulation, physical safety, and environment. To substantiate this, there is a case study carried out with the objective of implementing the nursing process in the care of a burned patient that listed as priority diagnoses the "Ineffective breathing pattern", the "Risk of infection", the "Impaired skin integrity" and the "Volume of deficient liquids"(7).

Burns lead to several physical changes that affect the body's homeostasis, including loss of fluid volume, either in the form of body edema, or through evaporation at the burn site, metabolic changes, body deformities, and risk of infection. Thus, nurses shall observe signs of hypoxemia, tachycardia, sweating, and cyanosis, respiratory response, and intervene in volume replacement and maintenance of large venous access in order to prevent hypovolemic shock ${ }^{(16)}$.

Regarding infection, patients at the Burn Treatment Center are more susceptible to it, because the burn is associated with the formation of devitalized tissues, degraded proteins, and decreased oxygen supply, potentiated by the length of hospital stay and the use of one or more invasive devices, factors that favor the development of sepsis, hinder the patients' rehabilitation, and can lead them to death ${ }^{(17)}$. Therefore, infection prevention measures that improve the quality of care become necessary, such as the promotion of a safe environment, the rigorous use of aseptic techniques, and the training of nursing professionals ${ }^{(16)}$. In certain cases, the debridement of the lesions is required to remove the tissue contaminated by bacteria and residues, to preserve the patient against bacterial invasion ${ }^{(18)}$.

In addition, it should be noted that the nurse's role in identifying, assessing, and treating pain in the burned patient is essential. In a study carried out in a public hospital, it was found that $61.8 \%$ of burned victims had pain complaints, of which $35.1 \%$ had moderate pain, $20.5 \%$ severe pain, and $6.2 \%$ mild pain. The patient's pain generates biological, emotional, and social consequences, and nursing interventions, either pharmacological (sedation and analgesia) or complementary ${ }^{(19)}$, are critical in their treatment.

The burned person also has losses in the thermal regulation mechanism, since one of the skin functions is the body temperature control. For this, the skin's thermoreceptors send information about the ambient temperature to the hypothalamus and it organizes appropriate responses of heat generation or dissipation, keeping the body temperature stable, around $37^{\circ} \mathrm{C}^{(20)}$. Thus, in the burned patient care setting, the nurse shall monitor the patient's body temperature, since skin loss can cause changes in the thermoregulation process ${ }^{(17)}$.

With regard to the psychobiological need for body care, the trauma caused by the burn can result in muscle weakness, severe muscle loss, contractures or other serious deformities or limiting deficiencies, which decrease the individuals' functional capacity when performing their daily activities, such as to walk or bathe ${ }^{(21)}$.

Regarding the psychosocial needs, the presence of the burn affects communication, sociability, recreation, and leisure and self-image, causing significant damage to the person affected. A burn trauma produces psychological stressors for several reasons, such as separation from family and work, bodily changes, loss of autonomy and expectations of the future, generating intense suffering. Victims suffer due to their body image, given the presence of scars, with possibilities of disfigurement, with feelings of insecurity, inferiority, and sadness, and emotional support from health professionals and family members is essential ${ }^{(15)}$.

Research carried out in a burn unit found that the burn significantly impacts the individual's quality of life, especially with regard to body image, affection, and skin sensitivity ${ }^{(22)}$. In another study, carried out at the Reference Center for Assistance to Burned Patients in a southern Brazilian hospital, the view on the quality of life of burned victims was discouraged due to changes in the life routine after trauma, among which the presence of scars, continuous dressings, the impossibility of sun exposure are highlighted, factors that contributed to anxiety and fear enhancement ${ }^{(23)}$.

In this context, the nurse shall promote comprehensive, safe and effective care, which provides comfort, hope, and support to the patient, in order to reduce their psychological suffering, encouraging their reintegration into society, as soon as possible. Psychobiological needs require more active monitoring from the nurse and the involvement and support of family members in the care process, since burns can produce varied emotional responses ${ }^{(17)}$.

Regarding spiritual needs, the diagnosis of "Spiritual Distress" was validated in this research. Spiritual distress is a condition of suffering that reinforces the individual's 
physical, emotional, and social pain, and encourages professionals from different areas of health to offer holistic care to the person who is experiencing a period of disharmony, since spirituality brings a positive response in coping with problems and health conditions ${ }^{(24)}$. However, as it is considered a complex, subjective, and abstract phenomenon, strategies, such as active listening and application of psychometric assessment, are required to facilitate the identification of spiritual distress in the clinical context in a more objective way $^{(25)}$.

The contribution of this study is substantiated in the possibility of creating a profile of diagnoses, results, and nursing interventions statements in the light of a classification system for support in the organization and implementation of managerial and nursing care actions. As these statements are identified and converge with the available scientific evidence, it is possible to solve and prevent problems, through careful nurse planning, a practical and decisive assistance plan. In addition, the recognition of such statements allows the development of care protocols, valorization of the nursing record, and the participation of the multiprofessional team based on the indications of the affected needs.

Based on the aspects above-mentioned, the advance of the ICNP ${ }^{\circledR}$ and its suitability to people who have suffered burns and need care in the hospital are inevitable. ICNP ${ }^{\circledR}$, over the years, has shown some progress, since several areas have been contemplated with the development of terminological subsets, thus contributing to a technological nursing apparatus that can impact people's well-being ${ }^{(26)}$.

The study presents as a limitation the subjectivity of the clinical evaluation, which can hinder the generalization of the terminological subset and its applicability in other scenarios. It should be highlighted that the method for the construction of the ICNP ${ }^{\circledR}$ terminological subsets has been adjusted by the researchers and the steps have been carried out in a non-uniform manner ${ }^{(3)}$. However, the elaboration of statements through clinical findings using the terminology mentioned contributes to the standardization of a scientific language, expanding the application of the nursing process.

\section{CONCLUSION}

The research allowed the elaboration of statements of a terminological subset containing 36 nursing diagnoses and results and 119 interventions for the care of burned patients based on the ICNP ${ }^{\circledR}$ and structured on the Theory of Basic Human Needs. Of the 36 validated diagnoses, 26 were classified within psychobiological needs, nine within psychosocial needs, and one within psycho-spiritual needs.

The potential of $\mathrm{ICNP}{ }^{\circledR}$ was evidenced as a terminology that enabled the construction of statements of nursing diagnoses based on the nursing practice phenomena listed in the health assessment of burned patients, allowing the analysis of the human responses of these individuals so that their real needs could be met.

\section{RESUMO}

Objetivo: Elaborar uma proposta de subconjunto terminológico da Classificação Internacional para a Prática de Enfermagem para pacientes queimados. Método: Estudo metodológico, seguindo-se as etapas: identificação de achados clínicos; mapeamento dos termos; construção dos enunciados de diagnósticos/resultados e intervenções de enfermagem; validação de conteúdo dos enunciados; e estruturação do subconjunto com o modelo teórico das Necessidades Humanas Básicas. A validação de conteúdo foi realizada por 26 enfermeiros especialistas, por meio do Índice de Validade de Conteúdo, sendo considerados validados enunciados $\geq 0,80$. Resultados: Foram validados 36 diagnósticos/resultados e 119 intervenções. Dentre estes, os que apresentaram maior índice foram: Função do Sistema Respiratório, Prejudicada/Função do Sistema Respiratório, Eficaz; Volume de Líquidos, Prejudicado/Volume de Líquidos, Eficaz; Ferida por Queimadura/Cicatrização de Ferida, Eficaz; Dor, Aguda/Dor, Ausente e como intervenções: Monitorar Sinais Vitais; Monitorar Equilíbrio de Líquidos; Tratar Condição da Pele; Avaliar Resposta ao Manejo (Controle) da Dor. Conclusão: Os enunciados validados retratam as necessidades humanas básicas de pessoas com queimaduras, sendo as psicobiológicas as mais predominantes.

\section{DESCRITORES}

Queimaduras; Cuidados de Enfermagem; Processo de Enfermagem; Terminologia Padronizada em Enfermagem; Classificação.

\section{RESUMEN}

Objetivo: Elaborar una propuesta de subconjunto terminológico de la Clasificación Internacional de la Práctica de Enfermería para pacientes quemados. Método: Estudio metodológico, siguiendo las siguientes etapas: identificación de hallazgos clínicos, mapeo de los términos; construcción de los enunciados de diagnósticos/resultados e intervenciones de enfermería; validación de contenido de los enunciados; y estructuración del subconjunto con el modelo teórico de las Necesidades Humanas Básicas. La validez de contenido fue realizada por 26 enfermeros expertos, por medio del Índice de Validez de Contenido, siendo considerados validados enunciados $\geq 0,80$. Resultados: Fueron validados 36 diagnósticos/resultados y 119 intervenciones. Entre esos, los que presentaron mayores índices fueron: Función del Sistema Respiratorio, Perjudicada/Función del Sistema Respiratorio, Eficaz; Volumen de Líquidos, Perjudicado Volumen de Líquidos, Eficaz; Herida por Quemadura/Cicatrización de Herida, Eficaz; Dolor, Aguda/Dolor, Ausente y como intervenciones: Monitorear Señales Vitales; Monitorear Equilibrio de Líquidos; Tratar Condición de la Piel; Evaluar Respuesta al Manejo (Control) del Dolor. Conclusión: Los enunciados validados retratan las necesidades humanas básicas de personas con quemaduras, siendo las biopsicológicas las más predominantes.

\section{DESCRIPTORES}

Quemaduras; Atención de Enfermería; Proceso de Enfermería; Terminología Normalizada de Enfermería; Clasificación. 


\section{REFERENCES}

1. Garcia TR, Nóbrega $M M L$, Cubas $M R$, organizadoras. Classificação Internacional para a Prática de Enfermagem - CIPE ${ }^{\circledR}$ : versão 2019/2020. João Pessoa: Centro de Pesquisa e Desenvolvimento da CIPE ${ }^{\circledR}$, Universidade Federal da Paraíba, 2019.

2. Pan R, Silva MTR, Fidelis TLN, Vilela LS, Silveira-Monteiro CA, Nascimento LC. Knowledge of health professionals concerning initial inhospital care for burn victims. Rev Gaúcha Enferm. 2018;39:e2017-0279. https://doi.org/10.1590/1983-1447.2018.2017-0279

3. Meneses LBA, Medeiros FAL, Oliveira JS, Nóbrega MML, Silva MA, Soares MJGO. Validation of interventions for Risk of Impaired Skin Integrity in adult and aged patients. Rev Bras Enferm. 2020;73(4):e20190258. http://dx.doi.org/10.1590/0034-7167-2019-0258

4. Carvalho CMG, Cubas MR, Nóbrega MML. Brazilian method for the development terminological subsets of ICNP ${ }^{\otimes}$ : limits and potentialities. Rev Bras Enferm. 2017;70(2):430-5. http://dx.doi.org/10.1590/0034-7167-2016-0308

5. Garcia TR. Classificação Internacional para a Prática de Enfermagem: CIPE ${ }^{\circledR}$ versão 2017. Porto Alegre: Artmed; 2017.

6. Silva RAR, Neto VLS, Moreira OAA, Santos FR, Santos RM, Padilha TMS. Proposta de plano de cuidados de enfermagem para paciente queimado: estudo de caso. REAID. 2017;80(18). https://doi.org/10.31011/reaid-2017-v.80-n.18-art.352

7. Souza Neto VL, Silva RAR, Costa RTS, Lucena EA, Silva SC, Pereira VM. Implementing the nursing process for a burn patient: a case study. Rev Enferm UERJ. 2018;26:e30962. http://dx.doi.org/10.12957/reuerj.2018.30962

8. Menezes HF, Camacho ACLF, Nóbrega MML, Fuly PSC, Fernandes SF, Silva RAR. Paths taken by Brazilian Nursing for the development of terminological subsets. Rev Latino Am Enfermagem. 2020;28:e3270. http://dx.doi.org/10.1590/1518-8345.3132.3270.

9. Horta WA. Processo de enfermagem. Rio de Janeiro: Guanabara Koogan; 2011.

10. Melo DM, Barbosa AJ. Use of the Mini-Mental State Examination in research on the elderly in Brazil: a systematic review. Ciênc Saúde Coletiva. 2015;20(12):3865-76. https://doi.org/10.1590/1413-812320152012.06032015

11. Fehring R. Methods to validate nursing diagnoses. Heart Lung. 1987;16(6):625-9.

12. International Organization for Standardization. ISO/TS 22789/2016: health informatics: conceptual framework for patient findings ad problems in terminologies. Geneva: ISO; 2016.

13. International Organization for Standardization. ISO 12300: health informatics: principles of mapping between terminological systems. Geneva: ISO; 2016.

14. Garcia TR, Bartz CC, Coenen AM. CIPE ${ }^{\circledR}$ : uma linguagem padronizada para a prática profissional. In: Garcia TR. Classificação Internacional para a Prática de Enfermagem: $\mathrm{CIPE}^{\circledR}$ aplicado à realidade brasileira. Porto Alegre: Artmed; 2016.

15. Viana FO, Eulálio KD, Moura LKB, Ribeiro IP, Ramos CV. Primary Health Care professionals' knowledge about initial burn care. Rev Bras Enferm. 2020;73(4):e20180941. http://dx.doi.org/10.1590/0034-7167-2018-0941

16. Jeschke MG, Baar ME, Choudhry MA, Chung KK, Gibran NS, Logsetty S. Burn injury. Nat Rev Dis Primers. 2020;6:11. https://doi. org/10.1038/s41572-020-0145-5

17. Nunez Lopez O, Cambiaso-Daniel J, Branski LK, Norbury WB, Herndon DN. Predicting and managing sepsis in burn patients: current perspectives. Ther Clin Risk Manag. 2017;13:1107-17. https://doi.org/10.2147/TCRM.S119938

18. Chan LC, Lee MS, Ou YN. Energy requirements for ICU burn patients in whom the total body surface area affected exceeds 50 percent: a practical equation. Asia Pac J Clin Nutr. 2018;27(6):1182-9. https://doi.org/10.6133/apjcn.201811_27(6).0003

19. Botelho Filho FM, Marçal IM, Roa L, Marinho AG, Ruiz GZL, Lopes LMC, et al. Analysis of the efficiency of an emergency network for the treatment of multiple burn victims. Rev Col Bras Cir. 2019;46(2):e2115. https://doi.org/10.1590/0100-6991e-20192115

20. Damatto RL, Cezar MDM, Santos PP. Control of body temperature during physical exercise. Arq Bras Cardiol. 2019;112(5):543-4. http:// dx.doi.org/10.5935/abc.20190081

21. Costa ACSM, Santos NS, Moraes PCM. Amplitude de movimento e sua interferência na capacidade funcional de pacientes com sequelas de queimaduras. Rev Bras Queimaduras. 2016;15(4):261-6.

22. Spronk I, Van Loey NEE, Sewalt C, Nieboer D, Renneberg B, et al. Recovery of health-related quality of life after burn injuries: an individual participant data meta-analysis. PLoS One. 2020;15(1):e0226653. https://doi.org/10.1371/journal.pone.0226653

23. Moraes LP, Echevarría-Guanilo ME, Martins CL, Longaray TM, Nascimento L, Braz DL, et al. Apoio social e qualidade de vida na perspectiva de pessoas que sofreram quaimaduras. Rev Bras Queimaduras. 2016;15(3):142-7.

24. Souza IA, Bastos NLMV, Vilela ABA, Sena ELS, Boery RNSO, Rocha RM. Espiritualidade e bioética nas questões sociais envolvendo a enfermagem. Rev Eletr Acervo Saúde. 2019;11(4):e276. https://doi.org/10.25248/reas.e276.2019

25. Simão T, Chaves E, lunes D. Spiritual distress: the search for new evidence. Rev Pesq Cuid Fundam Online. 2015;7(2):2591-602. http:// dx.doi.org/10.9789/2175-5361.2015.v7i2.2591-2602

26. Clares JWB, Guedes MVC, Freitas MC. Classificação Internacional para a Prática de Enfermagem nas dissertações e teses brasileiras. Rev Eletr Enferm. 2020;22:56262. https://doi.org/10.5216/ree.v22.56262 